$$
\text { JOES } \begin{aligned}
& \begin{array}{l}
\text { Journal } \\
\text { of Educational } \\
\text { Study }
\end{array}
\end{aligned}
$$

ISSN 2798-0650

Volume 1 Issue 22021

DOI: $10.36663 /$ joes.v1i2.151

\title{
Thinking Critically through Storytelling Technique: Enhancing Students' HOTS and English Speaking Skill
}

Kadek Trisna Kusuma Dewi, Ganesha University of Education, Bali trisnadewi610@gmail.com

\begin{abstract}
This study aims to investigate the effectiveness of using storytelling technique in enhancing students' critical thinking (HOTS) and English speaking skill in language learning. This study was designed by using library research method. This method is known as a method for collect data from various sources such as journal articles and books to write papers. The data was collected from several related literature reviews and which was qualitatively described. The finding showed that storytelling is to the use of storytelling shows that storytelling gives positive effect on students' in enhancing students' speaking skills and make them think critically (HOTS). Therefore, storytelling technique can be an effective's solution for teacher in enhancing students' critical thinking (HOTS) and their speaking skill in language learning.
\end{abstract}

Keywords: Storytelling, HOTS, English Speaking Skill

\section{Introduction}

Language is a tool in communicating or speaking with each other. In this case, as humans, we must be able to communicate or speak verbally. Among all subjects, language itself has a very important role for the intellectual, social, and emotional development of students in learning process. English is considered an international language. Yuniari (2018) said English is very important in the field of education. English is a global language used as a tool for communication by various countries. In some countries, English is a compulsory subject for students to study. Basic English should be taught since childhood. In addition to education, English can also be used for other purposes such as business, employment, etc. Four skills in English must be mastered by students namely listening, reading, speaking, and writing.

Speaking is one of the most important skill that should be mastered by students. Apart from listening, writing, and reading, one of the most crucial abilities in language acquisition is speaking. Speaking is the act of delivering and receiving information, such as in a conversation between two or more people (Arung, 2016). Brown (2001) as cited in Inayah (2015) describes speaking as an interconnected process in the context of the structure, which involves the 


\section{JOES $\begin{aligned} & \begin{array}{l}\text { Journal } \\ \text { of Educational } \\ \text { Study }\end{array}\end{aligned}$}

ISSN 2798-0650

Volume 1 Issue 22021

DOI: $10.36663 /$ joes.v1i2.151

production, acceptance, and management of information. As (2016) has said, speaking is a productive skill in which people generate words and send messages orally. Fauzan (2012) stated speaking is an action that involves using spoken language to communicate ideas and thoughts. Mastery of a language is demonstrated by the capacity to understand what others are saying and respond in the target language. According to Leong \& Ahmadi (2017), the integration of other language abilities demonstrates the relevance of speaking. Speaking helps students enhance their vocabulary and grammatical abilities before moving on to writing. Through speaking activities students can communicate their feelings and thoughts, tell stories, make requests, and talk, discuss, and show a variety of language skills. When students communicate verbally, they are expected to master knowledge about various aspects of speech such as comprehension, fluency, grammar, vocabulary, and pronunciation. While Khorashadyzadeh (2014) argues that speaking requires students not only to learn how to acquire linguistic skills such as grammar, pronunciation and vocabulary, but also to learn sociolinguistic skills such as where, why and how to speak. Bahadorfar and Omidvar (2015: 9) state that speaking skills can be classified as successful speaking skills when listeners could understand the words produced by the Speaker.

However, students sometimes have some problems that they generally face when they actually want to speak in front of the class. Ur (1996) as cited in Inayah (2015) says there are some difficulties in speaking activities. First is inhibition in the form of fear of making mistakes. Students are often hampered by fear that they will make mistakes or be criticized, also they are too ashamed to say words. Furthermore, students don't have anything to say. Students sometimes find mistakes that they don't have something to say. In other words, they cannot express themselves. Additionally, there is low or uneven participation of students to communicate. Only little student who eager and they dominated to speak, while others would be passive or just speak little or no at all. They also lack motivation in learning process. Last is the mother tongue that students use. In class, almost all students have the same mother tongue, so they feel it is not natural to speak in the foreign language. They often switched to speak their native language in order to continue expressing their idea. Therefore, make students more engage to share their thoughts, arguments or idea in speaking class is not an easy thing.

The education system has undergone changed continuously. Currently teaching Higher Order Thinking Skills (HOTS) proven because it plays a significant role in education. Students with HOTS (Higher Order Thinking Skills) are regarded more capable than those with Low Order Thinking Skills (LOTS). HOTS is also claimed to be related to student work readiness (Hasan \& Pardjono, 2019, cited in Purnama \& Nurdianingsih, 2019). According to Retnawati et al, (2018) HOTS can be described as the stage between the top three stages. Ability in cognitive aspects (analyzing, evaluating, and creating) and 3-dimensional knowledge levels (conceptual, procedural, and metacognitive). The taxonomy of Bloom's learning objectives was established in 1956 with six goals: knowledge, comprehension, application, analysis, synthesis, 


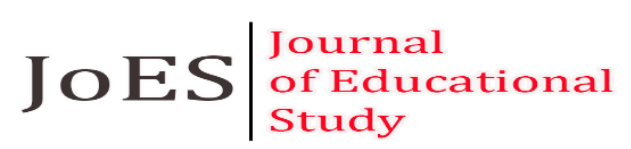

ISSN 2798-0650

Volume 1 Issue 22021

DOI: 10.36663/joes.v1i2.151

and evaluation. Activities in HOTS actually refers to student centered learning. In this case, students are encouraged to be able to use their critical thinking skills to find solutions to their problems in all learning aspects including English (Bloom, 1984 in Setyarini et al (2018). Brookhart (2010) stated there are three main characteristics of HOTS namely transfer, critical thinking and problem solving. For her, learning can be more than just recalling or comprehending, but the transfer of current information to another new environment, which is the cognitive component of knowledge based Bloom's taxonomy that has been revised. Students with HOTS (High Order Thinking Skills) are regarded more capable than those with Low Order Thinking Skills (LOTS). HOTS is also claimed to be related to student' readiness in facing the real world situation. Based on Bloom revised Taxonomy teaching HOTS covers analyzing (C4), evaluating (C5), and creating (C6). Activities in HOTS usually refer to student centered learning. In this case, students are encouraged to be able to use their critical thinking skills to find solutions to their problems in all learning aspects including English (Hasan \& Pardjono, 2019).

Teaching HOTS has a positive effect in teaching and learning English Language. In Purnama \& Nurdianingsih (2019), HOTS based on Bloom revised Taxonomy teaching HOTS covers analyzing (C4), evaluating (C5), and creating (C6). Sari (2020) claimed, in HOTS, the analysis is referred to the capacity of students to deconstruct and classify information systems into their respective classes and to define associations between the information components of the classification. These cognitive skills can be demonstrated using collect, plan, evaluate and create the following verbs. In addition, cognitive skills evaluating allows learners to justify the validity and accuracy of a piece of knowledge. Most HOTS activities are referred to adult learners to develop their reading and writing skills (Afshar \& Rahimi, 2016 as cited in Setyarini et al., 2018) and, in addition in terms of its use, HOTS can also improve students' speaking ability when expressing their point of view or thought. According to Sari (2020), Higher-Order Thinking Skills (HOTS) relates to the capability to connect knowledge, skills and concepts to thinking, interpretation, Problem-solving, decision-making, innovation and creativity to produce something new. Hence, HOTS are very significant for students in terms of build their critical thinking and it will prepare them to be ready in facing the real world in the future.

In research conducted by Akhyak \& Indrawan (2013), there are several advantages of speaking using storytelling: students feel that the teacher / lecturer gives them something very personal, often through telling stories it is easier to understand stories that are read aloud because telling stories gives motivation, meaning, fluency, language awareness, and stimulus for students to speak. Furthermore, according to Setyarini et al., (2018), Storytelling can boost students' ability to communicate. The researcher observed that enhancing students' ability to speak derives from their eagerness to offer thoughts, comments, and arguments in the discussion. Several researchers carried out similar studies. The first study was conducted by Setyarini (2016) entitled Higher Order Thinking (HOTs) in storytelling: An innovative learning model to improve 


\section{JOES $\begin{aligned} & \begin{array}{l}\text { Journal } \\ \text { of Educational } \\ \text { Study }\end{array}\end{aligned}$}

ISSN 2798-0650

Volume 1 Issue 22021

DOI: 10.36663/joes.v1i2.151

speaking skill of grade seventh students in Bandung. This study aims to investigate how higher order thinking in storytelling is taught to 7 th grade students to improve their speaking skills. The planning, action, reflection, and evaluation processes of this classroom action study were completed in two cycles. Classroom observations, interviews with students, and documentation in the form of student stories were used to gather data. The findings showed that using openended questions like "why," "how," "what if," and "how" in storytelling can help students improve their speaking skills. This type of question encourages students to express their thoughts and arguments about the story by drawing on prior knowledge and experience. Furthermore, students' speaking skills develop as a result of their active involvement in group or pair conversations.

Another study conducted by Setyarini \& Ling (2019) carried out a study entitled Promoting higher order thinking skills in storytelling for teaching English to young adolescents in 21st century. This research focused on how Higher Order Thinking Skills are used to teach English to young teenagers through storytelling. To obtain data, ethnographic research using three instruments was used. Participants were chosen from three classes from three different schools. According to the findings, HOTs were encouraged to use a variety of strategies to teach English to young adolescents in all learning sessions, including asking questions, mind mapping, brainstorming, role-playing, asking questions, discussing, and creating new ideas that were arranged in storytelling. This learning style appeals to students because it allows them to express their thoughts critically without fear of being judged. They can also use their prior knowledge and experience to help them.

Zahroh (2020) carried out a study with the topic Integrating Higher-Order Thinking Skills (HOTS) to Increase Students' Productive Skills. The aim of this study was gives an overview of several ideas and research on the integration of higher order thinking skills (HOTS) to help English as a Foreign Language (EFL) learners to enhance their productive skills. Several previous research in this study showing the advantages of higher order thinking skills in learning English, as well as study findings on the impact of higher order thinking skills on English language learners, form the major subject of future discussion. Based on previous theories and studies, it can be found that the use of higher order thinking skills in classroom activities plays a significant role, particularly in teaching English, and it provides substantial advantages for both students and teachers.

Based on those previous studies, it can be concluded that both Speaking and HOTS skill are essential to be enhanced in the language learning. Storytelling can be a great solution to enhance the Speaking and HOTS skill of students. Therefore, this study aims to find out the effectiveness of using Storytelling in enhancing students' HOTS and English speaking ability in the learning process. 


\section{JoES $\mid \begin{aligned} & \text { Journal } \\ & \text { of Educational } \\ & \text { Study }\end{aligned}$}

ISSN 2798-0650

Volume 1 Issue 22021

DOI: 10.36663/joes.v1i2.151

\section{Method}

This study was designed by using library research method. This method is known as a method for collect data from various sources such as journal articles and books to write papers. The data was collected from several related literature reviews and which was qualitatively described. It aims to conduct the data from relatable studies that support the validity of current research. The data that has been collected is used to support the statement that Storytelling technique provides several advantages to enhance students' critical thinking (HOTS) and speaking skills in learning activities. The theories used are collected from various relatable article journals to obtain appropriate data and information. Journal articles are used to reinforce data on the effectiveness of using Storytelling in enhancing students' HOTS and their speaking ability in the learning process. It was started from reading some relatable article or journals from various sources, classifying data, and analyzing data to answer research issues in the form of descriptions on finding and discussion.

\section{Findings}

HOTS stands for Higher Order Thinking Skills. HOTS may be defined as the stage in between the top three stages, according to Retnawati et al. (2018), as cited in Sari (2020). Cognitive abilities (analyzing, evaluating, and producing) as well as three-dimensional knowledge levels (conceptual, procedural, and metacognitive). Bloom's taxonomy learning objectives was created in 1956 and includes six goals: knowledge, comprehension, application, analysis, synthesis, and evaluation. The term "activities" in HOTS refers to student-centered learning. In this case, students are encouraged to utilize their critical thinking abilities to solve issues in all parts of their study, including English (Bloom, 1984 in Setyarini, Muslim, Rukmini, Yuliasri, \& Mujianto (2018). According to Brookhart (2010), HOTS has three major characteristics: transfer, critical thinking, and problem solving. Learning, according to him, might entail more than just remembering or comprehending; it can also entail transferring existing information to a new context, which is the cognitive component of Bloom's updated knowledge-based taxonomy.

Storytelling is the activity to retell the story based on something that had been read or experience of the storyteller using their own word or their understanding about the story. Coconi (2013) as cited in Inayah (2015) defining the act of conveying experiences through the use of words and sounds is known as storytelling. One approach to learn a new language in the classroom is through storytelling. This activity entails the introduction of new language vocabularies through the creation of stories using those vocabularies (Marzuki et al., 2016). Safdarian (2012) describes storytelling as a way for students to narrate stories in different words after they have been taught by teachers. In addition, Ling in Julia (2015:14) as cited by Zuhriyah (2017) argues that storytelling is a learning-centered technique that helps students to use information and it's delivering the information to others. Furthermore Ellis \& Brewster (2014) 


\section{JoES $\mid \begin{aligned} & \text { Journal } \\ & \text { of Educational } \\ & \text { Study }\end{aligned}$}

ISSN 2798-0650

Volume 1 Issue 22021

DOI: 10.36663/joes.v1i2.151

adds that the language in the story in a clear context and illustration might aid students in conveying ideas. Fun contexts and circumstances can help students recall the terminology in the story. As (2016) said storytelling has great value for teachers in terms of creating a comfortable and fun environment in the classroom.

From some previous study that related to the use of storytelling shows that storytelling give positive effect on students' in enhancing students' speaking skills and make them think critically (HOTS). According to Akhyak \& Indrawan (2013), there are several advantages of storytelling namely students feel that the teacher / instructor gives them something very personal; it is often easier to comprehend stories that are read aloud because telling stories provides motivation, meaning, fluency, language awareness, and stimulus for students to speak. Considering the necessary role of storytelling in children's language learning process, it may also be used to improve their critical thinking competence. In all learning sessions, HOTs were encouraged to utilize a range of techniques to teach English to young adolescents, such as asking questions, mind mapping, brainstorming, role playing, asking questions, debating, and coming up with new ideas that are structured in storytelling. Students like this learning approach because it allows them to express themselves critically without fear of being judged (Setyarini et al., 2018).

\section{Discussions}

There are some advantages of storytelling in improving students' speaking skill. Besides, storytelling also effective to enhance students' HOTS (Higher Order Thinking Skills). Douglas and Gomes (1997) argue that storytelling activities will encourage communication, promote the creativity of students and facilitate their contribution in the class. Storytelling may also be means developing students ' oral communication skills, because oral discussion of narrative material helps students to refer to their own life experiences using higher-level thinking skills (Thomas \& Thorne, 2009). Douglas and Gomes (1997) added that storytelling technique will stimulate opinion, activate the creativity of students and facilitate their engagement in their classroom activities. In addition, the plot or narrative is often related to cultural comprehension. This competence is an essential part of the critical thinking skills that young students must succeed to be prepared to invest with the future of the global world.

According to Setyarini and Ling (2019) there are several teaching activity that applied HOTS through storytelling techniques:

1. First, show pictures and ask some questions to students.

2. Secondly, give a model of retelling the stories.

3. Third, ask the students to form a group, give a copy of the story to the groups, and ask them to read. 


\section{JOES $\mid \begin{aligned} & \text { Journal } \\ & \text { of Educational } \\ & \text { Study }\end{aligned}$}

ISSN 2798-0650

Volume 1 Issue 22021

DOI: 10.36663/joes.v1i2.151

4. Fourth, ask students to make questions then share those questions with their friends,

5. Next, ask students to retell about the story that they have read and associate it with the things they experienced, ask questions, and answer questions,

6. Furthermore, ask students to find the problems found in the article and discuss the solution of those problems.

7. Then, require students to ask teachers, teachers explain and provide solutions to students' problems.

8. Lastly remind the difficulty of students and solutions how they can solve their problems.

Those activities cannot be carried out only in one meeting, therefore these will be conducted in four meetings. It can be concluded that storytelling technique is beneficial to be applied in the language learning process in order to build students' critical thinking that refers to HOTS (Higher Order Thinking Skills) and their speaking ability. Moreover, the difficulties of teaching speaking and build students' critical thinking to convey their arguments or idea in the learning process can be helped by storytelling technique. Therefore, storytelling technique can be a great solution to be used in enhancing students' critical thinking (HOTS) and their speaking skill in language learning. Moreover, based the difficulties of teaching speaking and build students' critical thinking to convey their arguments or idea in the learning process can be helped by storytelling technique. Therefore, storytelling technique can be a great solution to be used in enhancing students' critical thinking (HOTS) and their speaking skill in language learning.

\section{Conclusions and Suggestions}

This study aims to investigate the effectiveness of using storytelling technique in enhancing students' critical thinking (HOTS) and English speaking skill in language learning. Speaking is considered as one of the most important skill that should be mastered by students. However, teaching speaking is not an easy thing, there can be some difficulties that are suffered by students in conveying their thoughts or idea. Recently, the education system has undergone changed continuously. Currently teaching Higher Order Thinking Skills (HOTS) proven because it plays a significant role in education. Students with HOTS (Higher Order Thinking Skills) are regarded more capable than those with Low Order Thinking Skills (LOTS. In order to achieve both speaking and HOTS skills of students, the appropriate technique needs to be chose by the teacher in enhancing those competences. Storytelling technique can be great solution to be applied in order to improve both students' speaking ability and HOTS (Higher Order Thinking Skills). It is because storytelling can be proved as a beneficial technique to be applied which it will encourage students to communicate, promote their creativity of and facilitate them to engage in their classroom activities. Therefore, storytelling technique can be an effective's solution for 


\section{JOES $\begin{aligned} & \begin{array}{l}\text { Journal } \\ \text { of Educational } \\ \text { Study }\end{array}\end{aligned}$}

ISSN 2798-0650

Volume 1 Issue 22021

DOI: 10.36663/joes.v1i2.151

teacher in enhancing students' critical thinking (HOTS) and their speaking skill in language learning.

\section{References}

Akhyak \& Indramawan, A. (2013). Improving the students' English speaking competence through storytelling (Study in Pangeran Diponegoro islamic college (STAI) of Nganjuk, East Java, Indonesia). International Journal of Language and Literature, 1(2), 18-24. I

Arung, F., \& Jumardin, J. (2016). Improving the students' speaking skill through debate technique. Journal of English Education, 1(1), 70-76.

As, A. B. (2016). Storytelling to improve speaking skills. English Education Journal, 7(2), 194205.

Bahadorfar, M. \& Omidvar, R. (2015). Technology in teaching speaking skill. Acme International Journal of Multidisciplinary Research, 2(4), 9-13.

Brookhart, S. M. (2010). How to assess higher-order thinking skills in your classroom. ASCD.

Douglas, F., \& Gomes, P. J. (1997). Narrative of the life of Frederick Douglass, an American slave. New York: Signet Classic.

Fauzan, U. (2012). Improvisations Technique in the Teaching of Speaking. Media Akademika, 27(2), 145-165.

Hasan, A., \& Pardjono, P. (2019). The Correlation of Higher Order Thinking Skills and Work Readiness of Vocational High School Students. Jurnal Pendidikan Teknologi dan Kejuruan, 25(1), 52-61.

Inayah, R. (2015). IMPROVING STUDENTS'SPEAKING SKILL THROUGH STORYTELLING TECHNIQUE (An Experimental Study in a Senior High School in Bandung). ELTIN JOURNAL, Journal of English Language Teaching in Indonesia, 3(1).

Khorashadyzadeh, A. (2014). Why to use short stories in speaking classes. International Journal of Foreign Language Teaching in the Islamic World, 2(1), 9-15.

Leong, L. M., \& Ahmadi, S. M. (2017). AN ANALYSIS OF FACTORS INFLUENCING LEARNERS'ENGLISH SPEAKING SKILL.

Marzuki, M., Prayogo, J. A., \& Wahyudi, A. (2016). Improving the EFL learners' speaking ability through interactive storytelling. Dinamika Ilmu: Jurnal Pendidikan, 16(1), 15-34.

Purnama, Y. I., \& Nurdianingsih, F. (2019). The Impact of Higher Order Thinking Skills (HOTS) Instructions in Teaching EFL Speaking Skill from the Perspective of Students' Motivation. Lingua Cultura, 13(4), 313-319.

Retnawati, H., Djidu, H., Kartianom, A., \& Anazifa, R. D. (2018). Teachers' knowledge about higher-order thinking skills and its learning strategy. Problems of Education in the $21 \mathrm{st}$ Century, 76(2), 215.

Samantaray, P. (2014). Use of storytelling method to develop spoken English skill. International Journal of Language \& Linguistics, 1(1), 40-44.

Sari, N. I. THE USE OF HIGHER ORDER THIKING SKILL (HOTS) TO IMPROVE STUDENTS'SPEAKING ABILITY.

Setyarini, S. (2016). Higher Order Thinking (HOTs) in storytelling: An innovative learning 


\section{JOES $\mid \begin{aligned} & \text { Journal } \\ & \text { of Educational } \\ & \text { Study }\end{aligned}$}

ISSN 2798-0650

Volume 1 Issue 22021

DOI: 10.36663/joes.v1i2.151

model to improve speaking skill of grade seventh students in Bandung. In The 4th Literary Studies Conference (Vol. 196).

Setyarini, S., Muslim, A. B., Rukmini, D., Yuliasri, I., \& Mujianto, Y. (2018). Thinking critically while storytelling: Improving children's HOTS and English oral competence. Indonesian Journal of Applied Linguistics, 8(1), 189-197.

Setyarini, S., \& Ling, M. A. (2019). Promoting higher order thinking skills in storytelling for teaching english to young adolescents in 21st century. KnE Social Sciences, 155-164.

Safdarian, Z. (2012). THE EFFECT OF STORIES ON YOUNG LEARNERS'PROFICIENCY AND MOTIVATION IN FOREIGN LANGUAGE LEARNING (Doctoral dissertation, Kharazmi University).

Thomas, A., \& Thorne, G. (2009). The strategies for enhancing higher order thinking. Metarie, LA.: Center for development and learning.

Yuniari, N. M. (2018). The Effect of Using Powtoon Audiovisual Media Upon the Students' Writing Achievement of the Third Semester Students of English Eduacation Departement Faculty of Teacher Training and Pedagogy Dwijendra University. Widya Accarya, Vol. 9 No. http://ejournal.undwi.ac.id/index.php/widyaaccarya/article/view/668

Zahroh, S. (2020). Integrating Higher-Order Thinking Skills (HOTS) to Increase Students' Productive Skills.

Zare-Behtash, E., Saed, A., \& Sajjadi, F. (2016). The effect of storytelling technique on speaking ability of female Iranian intermediate EFL learners. International Journal of Applied Linguistics and English Literature, 5(1), 209-214.

Zuhriyah, M. (2017). Storytelling to improve students'speaking skill. English Education: Jurnal Tadris Bahasa Inggris, 10(1), 119-134. 